\title{
PENGEMBANGAN PROGRAM SOSIOMETRI SEBAGAI MEDIA PENGUNGKAPAN HUBUNGAN SOSIAL SISWA SMAN 9 MAKASSAR
}

\author{
Akhmad Harum \\ Bimbingan dan Konseling, Universitas Negeri Makassar \\ email: harumakhmad@gmail.com \\ Abdul Saman \\ Bimbingan dan Konseling, Universitas Negeri Makassar \\ email: abdulsaman72@gmail.com \\ Muhammad Anas Malik \\ Bimbingan dan Konseling, Universitas Negeri Makassar \\ email: muhammadanasmalik@yahoo.com
}

\begin{abstract}
This study aims to produce an application program sociometry connected to a computer which included a media component to analyze data sociometry and instruments sociometry at high school students are directly usable by a tutor to fill out an application and be able to know the students' social relationships. The research model development refers to the opinion of Brog \& Gall namely procedural development model which is further modified by the researcher. The subjects of this study is divided into subject experts, namely the subject of the instrument experts, IT and tutor as well as the subject of the trial, namely 63 students in grades 2 and 3 in grade 3 and overall supervising teacher at SMAN 9 Makassar. Withdrawal of study subjects using stratified random sampling technique. Data was collected through interviews, feasibility studies, questionnaire and documentation. Results of research and development completed with two stages of the test, the test experts (expert validation and test of small groups, as well as two stages of the revision, including revision based on expert testing and revisions based on testing small groups. Based on the feasibility study by expert test the general program sociometry as media disclosure of social relations student gets $4.26 \%$ grading scale that is in the category feasible and based on a small group of test programs sociometry at acceptance tests as much as $90 \%$ (very high) products declared unacceptable and keterpakaian test as much as $90 \%$ (very high) products otherwise it can be used / implemented.
\end{abstract}

Keywords: Development, program sosiomentri, social relations
Abstrak: Penelitian ini bertujuan menghasilkan aplikasi program sosiometri yang terhubung dengan computer, pada aplikasi terdapat komponen media untuk menganalisis data sosiometri dan instrumen sosiometri pada siswa SMA yang langsung dapat digunakan oleh guru pembimbing dengan mengisi aplikasi itu dan dapat mengetahui hubungan sosial siswa. Menggunakan model pengembangan, dengan prosedural yang selanjutnya dimodifikasi oleh peneliti. Subyek penelitian ini terbagi atas subyek ahli, yaitu subyek ahli instrumen, TI dan guru pembimbing serta subyek uji coba yaitu 6 orang siswa 3 di kelas 2 dan 3 di kelas 3 serta keseluruhan guru pembimbing di SMAN 9 Makassar. Penarikan subyek penelitian menggunakan teknik stratified random sampling. Teknik pengumpulan data adalah wawancara, uji kelayakan, angket dan dokumentasi. Hasil penelitian pengembangan diselesaikan dengan dua kali tahap uji, yaitu uji ahli, serta dua kali tahap revisi, meliputi revisi berdasarkan uji ahli dan revisi berdasarkan uji kelompok kecil. Berdasarkan uji kelayakan oleh uji ahli secara umum program program sosiometri sebagai media pengungkapan hubungan sosial siswa mendapat skala penilaian 
4,26\% yang berada pada kategori layak dan berdasarkan uji kelompok kecil program program sosiometri pada uji keberterimaan sebanyak $90 \%$ (sangat tinggi) produk dinyatakan dapat diterima dan uji keterpakaian sebanyak 90\% (sangat tinggi) produk dinyatakan dapat digunakan/dilaksanakan.

Kata Kunci: Pengembangan, program sosiometri, Hubungan sosial

\section{PENDAHULUAN}

Perkembangan teknologi komputer yang begitu pesat tanpa kita sadari membawa dampak pada lingkungan kerja berbagai bidang. Khususnya guru pembimbing setidaknya memiliki kompetensi dibidang teknologi yang mendukung profesionalitasnya dalam pelayanan konseling. Kekhawatiran yang muncul saat ini kompetensi teknologi yang dimiliki guru pembimbing hanya menekankan pada domain pembelajaran kognitif yaitu kompetensi teknologi yang hanya sebatas pengetahuan dan keterampilan yang berhubungan dengan penggunaan teknologi, seharusnya yang lebih penting adalah bagaimanana untuk fokus pada membangun sikap positif terhadap penggunaan dan pengaplikasian teknologi komputer bagi profesi konseling.

Selanjutnya, dalam rangka pembangunan sumber daya manusia dan menciptakan hubungan sosial yang optimal sebuah institusi pendidikan merupakan sarana dan wahana yang sangat baik dalam pembinaan sumber daya manusia terutama dalam hal hubungan sosialnya. Oleh karena itu pendidikan perlu mendapat perhatian yang lebih serius baik itu oleh pemerintah, keluarga maupun pengelola pendidikan khususnya. Dengan perkembangan teknologi yang semakin pesat, sarana dan prasarana pendidikan pun harus mengikutinya, salah satunya dengan media komputer.

Eksploitasi potensi untuk memanfaatkan teknologi komputer dalam setting konseling sangat dipengaruhi oleh kemampuan diri pribadi guru pembimbing. Ini dapat dibuktikan dengan minimnya jumlah guru pembimbing yang muncul di dunia internet. Dalam kenyataan di lapangan pun tidak banyak guru pembimbing yang mahir mengoperasikan perangkat komputer. Guru pembimbing perlu melatih diri untuk mampu mengoperasikan perangkat komputer, hal ini dapat dilakukan baik secara individu maupun kelompok. Permasalahan ini harus segera ditangani dan menjadi tanggung jawab kita semua yang peduli pada eksistensi profesi guru pembimbing di masa datang.

Untuk itu guru pembimbing dapat berlatih dimulai dengan menggunakan perangkat komputer dalam kegiatan administrasi konseling seperti membuat satuan layanan, himpunan data siswa, analisis data hasil instrumenasi, pembuatan laporan dan keperluan administrasi lainnya. Salah satu kegiatan instrumentasi yang sering digunakan oleh guru pembimbing adalah sosiometri. Sosiometri merupakan salah satu metode psikologi sosial yang dikembangkan oleh Jacob Lewi Moreno, MD (1889-1974), seorang dokter yang beralih profesi sebagai psikiater, dibesarkan di Vienna, kemudian pindah ke Amerika Serikat pada 1925, dan bekerja di bagian utara Negara bagian New York pada 1930an. Sejak saat itu sosiometri dikenal dan digunakan sebagai salah satu cara untuk mengukur tingkat hubungan sosial antar individu dalam kelompok.

Hubungan sosial antar individu dalam kelompok pada umumnya dapat diketahui pada masa SMA. Hal ini disebabkan karena pada dasarnya masa SMA atau yang lebih sering disebut masa remaja merupakan masa peralihan di antara masa kanak-kanak dan dewasa. Dalam masa ini anak mengalami pertumbuhan dan masa perkembangan fisik maupun perkembangan psikis. Mereka bukanlah anak-anak baik bentuk badan ataupun cara berfikir dan bertindak, tetapi bukan pula orang dewasa yang telah matang. Usia remaja sangat rentan dengan keadaan lingkungan dan pergaulan. Pada era sekarang ini remaja telah terkontaminasi dengan perkembangan zaman dan teknologi yang disalahgunakan sesuai dengan paradigma yang terkandung dalam diri seorang remaja maka perkembangan teknologi tidak terarah ke perubahan yang positif malah menjadikan remaja menuju ke hal-hal negatif yang membentuk pribadi salah satunya adalah terciptanya hubungan sosial yang tidak optimal.

Hubungan sosial antar individu dalam kelompok yang terjadi pada kalangan siswa 
SMA sebagai usia remaja akan semakin berkembang, karena adanya dorongan rasa ingin tahu terhadap segala sesuatu yang ada di dunia sekitarnya. Menurut Ali dan Asrori (2004: 85) bahwa "dalam perkembangannya, setiap individu ingin tahu bagaimana cara melakukan hubungan secara baik dan aman dengan dunia sekitarnya, baik bersifat pribadi maupun sosial". Menurut Sarwono (1996: 86) mengemukakan "hubungan sosial adalah hubungan manusia dengan manusia lainnya atau hubungan manusia dengan kelompok atau hubungan kelopmpok dengan kelompok. Hal ini menunjukkan bahwa setiap individu memiliki hasrat untuk melakukan hubungan sosial yang dilatarbelakangi oleh berbagai faktor seperti adanya persamaan kepentingan, hobby atau bahkan pada situasi dan kondisi yang sama, seperti halnya siswa di sekolah yang berada pada kepentingan yang sama.

Untuk mencapai hubungan sosial yang optimal banyak faktor yang mempengaruhinya. salah satu diantaranya adalah terbinanya hubungan antar teman yang baik dalam berinteraksi. Namun pada umumnya guru pembimbing tidak pernah mengetahui siswasiswa yang memgetahui siswa-siswa yang memiliki hubungan antar teman yang baik dan sebaliknya terutama dalam berinteraksi ini akibatnya jika guru pembimbing kurang pendekatan dengan siswa dan kurang bijaksana, guru pembimbing tidak akan melihat bahwa di dalam kelas ada kelompok yang saling bersaing secara tidak sehat sehingga suasana kelas tidak menyenangkan, bahkan hubungan sosial masingmasing siswa tidak baik.

Untuk melihat hubungan sosial yang terjadi dalam suatu kelompok atau kelas berbagai cara bisa dilakukan, salah satunya adalah dengan menggunakan instrumen pengumpulan data yaitu sosiometri. Sosiometri didasarkan pada kenyataan bahwa setiap orang membuat pilihan dalam hubungan antar pribadi. Hal ini diperkuat oleh Siahaan (2005) sosiometri adalah suatu metode pengumpulan serta analisis data mengenai pilihan, komunikasi dan pola interaksi antar-individu dalam kelompok dan senada dengan Rusmana (2009) sosiometri adalah suatu teknik analisis untuk mempelajari interaksi sosial dan mencari tahu apa siapa yang disukai orangorang dan dengan siapa mereka akan atau tidak akan bersedia bekerja sama.
Software ini telah lama di kembangkan oleh Eko Susanto dan dipasarkan diinternet dan tersedia versi trial 30 hari yang dapat didownload secara gratis. Software ini dibuat dengan menggunakan bahasa Inggris bahkan sudah ada yang berbahasa Indonesia. Penggunaan software telah berkali-kali diuji cobakan di beberapa sekolah di Sumatera Barat bahkan sudah disajikan pada workshop nasional di Kota Bukit Tinggi dan Kota Pariaman. Hasil uji lapangan dari software sosiometri yang dimaksud ternyata sangat membantu guru pembimbing dalam pengolahan angket sosiometri, dengan bantuan software ini guru pembimbing secara mandiri dapat mengolah hasil angket sosiometri dengan mudah. Tampilan dan cara menggunakan software sosiometri ini relatif sederhana dan mudah digunakan. Namun itu belum cukup membantu guru pembimbing karena masih perlu didownload setiap 30 hari masa pemakaian dan aplikasi yang berada di dalam software ini masih perlu dikembangkan seperti menambahkan instrumen sosiometri menjadi empat bidang bimbingan seperti bidang bimbingan probadi, belajar, sosial dan karir, tabulasi data dan sosiogram yang per individu dan tak lupa pula desain sofware pun di kembangkan sehingga menjadi lebih sempurna. Untuk itu perlu produk baru yang bisa mengatasi hal itu demi terwujudnya hubungan sosial antar individu dalam kelompok yang optimal.

Selama ini instrumen pengumpulan data berupa sosiometri diseluruh SMA/SMK sekota Makassar penggunaannya masih jauh dari apa yang diharapkan. Hal ini dibuktikan dengan observasi peneliti pada sekolah yang ada di kota Makassar. Hasilnya pada umumnya sekolahsekolah tersebut jarang sekali memberikan instrumen ini kepada siswa. Bahkan hasil observasi peneliti terhadap guru pembimbing di sekolah itu ditemukan bahwa masih ada sebagian guru pembimbing yang belajar cara menggunakan alat pengumpulan data ini. Dengan hasil observasi dibeberapa sekolah mengenai fenomena penggunaan Program sosiometri ini yang ada di kota Makassar ternyata ada satu sekolah yang menjadi perhatian untuk menjadi objek observasi peneliti yaitu SMAN 9 Makassar ternyata pada umumnya di sekolah tersebut jarang menggunakan instrumen ini kepada siswa dalam melihat hubungan sosial antara siswa yang satu dengan yang lainnya. 
Dari hasil observasi peneliti di sekolah diperoleh informasi bahwa alat pengumpulan data sosiometri ini juga selama ini masih bersifat manual dalam hal proses analisis data sosiometri dan butuh produk yang baru dalam membantu guru pembimbing untuk mempermudah menganalisis data sosiometri demi terwujudnya hubungan sosial yang optimal. Berdasarkan uraian di atas, peneliti tertarik untuk mengembangkan suatu produk yang bisa membantu guru pembimbing di sekolah pada proses analisis data siswa yaitu berupa instrumen program sosiometri sebagai media pengungkapan hubungan sosial siswa SMA yang berbasis komputer.

\section{METODE}

Dalam penelitian pengembangan ini, peneliti menggunakan model pengembangan prosedural, yaitu model yang bersifat deskriptif dimana dalam penelitian ini peneliti membuat langkah-langkah yang harus diikuti untuk menghasilkan produk (Wasis, 2004: 15). Model pengembangan tersebut mengacu pada strategi pengembangan yang dikemukakan oleh Borg and Gall (1983: 150) karena model ini mempunyai langkah-langkah yang dianggap paling sesuai dengan penelitian ini. Strategi ini dinamakan penelitian dan pengembangan (Research and Development). R\&D merupakan siklus pengembangan yang terdiri dari 8 langkah pengembangan, yaitu:

1) Analisis Kebutuhan: mengidentifikasi kebutuhan subyek akan produk yang akan di kembangkan.

2) Penelitian awal dan pengumpulan informasi: Karakteristik siswa, Studi Literatur dan Perumusan masalah

3) Perencanaan Pengembangan: merumuskan tujuan pengembangan dan menentukan materi yang akan dikembangkan.

4) Pengembangan produk awal: desain produk, mengelolah aplikasi, pembuatan produk

5) Uji ahli (validasi ahli

6) Revisi I

7) Uji coba kelompok

8) Revisi II

Adapun dalam penelitian pengembangan ini dikembangkan dengan menggunakan aplikasi komputer berupa program Microsoft office excel dengan software pro 2,3 yang menghasilkan aplikasi program analisis data sosiometri berupa instrumen empat bidang bimbingan (bimbingan Pribadi, belajar, sosial, dan karir), tabulasi data, sosiogram per item pertanyaan, grafik, analisa individu dan kelompok sertan desain program sebagai media pengungkapan hubungan sosial siswa SMA.

Penelitian pengembangan ini dilakukan pada siswa SMAN 9 Makassar setelah terlebih dahulu mengadakan observasi untuk memperoleh data informasi. Subyek penelitian ini terbagi menjadi dua subyek yaitu subyek uji ahli dan subyek uji coba. Penarikan sampel dilakukan dengan cara stratified random sampling dimana sampel tersebut diacak berdasarkan tingkatan kelas. Adapun kriterianya adalah ahli dalam bidang instrumen pengumpulan data yaitu Dosen PPB yaitu Drs. Muhammad Ibrahim, M.Si, TI yaitu Dr. Pattaufi, M.Pd dan guru pembimbing yang punya kulaitas yang baik yaitu Drs. Kasrun Kasiran, M.Pd.

Pada pengembangan program sosiometri ini menggunakan uji coba. Subyek uji kelompok kecil merupakan sekelompok kecil siswa kelas 2 dan 3 yaitu 6 orang. Kelas 2 sebanyak 3 siswa dan kelas 3 sebanyak 3 siswa. Sampel tersebut diambil menggunakan stratified random sampling, dimana sampel tersebut diacak berdasarkan tingkatan kelas.

Penelitian ini menggunakan empat macam instrumen pengambilan data yaitu interview berupa wawancara bebas terpimpin untuk mengetahui kejelasan media program sosiometri dan tampilan programnya, uji kelayakan berupa evaluasi dari segi materi dan kelayakan program, angket untuk megetahui tanggapan dan penilaian siswa SMA berupa pernyataan tertutup "ya atau tidak" dan dokumentasi berupa foto, gambar dan hasil wawancara dan angket. Validitas instrumen dalam penelitian pengembangan ini khususnya berupa angket dilakukan dengan cara validitas logis.

Teknik analisis data yang digunakan untuk mengolah data yang diperoleh dalam pengembangan media program sosiometri ini adalah dengan menggunakan analisis kualitatif isi berupa tanggapan, masukan, serta kritik dan saran yang didapat dari para ahli, ini digunakan untuk merevisi media tahap awal dan analisis deskriptif dan analisis data kuantitatif dilakukan dengan analisis deskriptif kuantitatif, yaitu untuk menganalisis data kuantitatif yang 
diperoleh dari angket lembar evaluasi yang diperoleh dari uji coba kelompok.

\section{HASIL DAN PEMBAHASAN}

Penelitian dan Pengumpulan Informasi. Dari hasil survey melalui wawancara, diketahui bahwa program Program sosiometri sebagai media pengungkapan hubungan sosial siswa belum ada di sekolah tersebut. Ketika peneliti menyampaikan bahwa peneliti akan melakukan penelitian pengembangan Program sosiometri sebagai media pengungkapan hubungan sosial siswa di SMAN 9 Makassar tersebut, guru pembimbing menyambut baik recana dari peneliti.

Analisis kebutuhan. Dari hasil wawancara dengan 6 orang siswa kelas XI dan XII SMAN 9 Makassar, didapatkan data yang dapat disimpulkan bahwa hampir semua jenjang kelas dua maupun kelas tiga membutuhkan suatu program E-sosiometri, agar mereka dapat mengetahui hubungan sosial siswa antara yang satu dengan yang lainnya sehingga dapat tercipta hubungan sosial yang optimal.Hasil wawancara berdasarkan pedoman wawacara pada 6 orang siswa kelas XI dan XII SMAN 9 Makassar adalah sebagai berikut:

Dari 6 orang siswa kelas XI dan XII hanya 2 siswa yang mengetahui tentang ESosiometri, selebihnya hanya pernah mendengar tentang E-Sosiometridan tidak tahu tentang ESosiometri. Selanjutnya dari penuturan mereka siswa kelas XI belum pernah diberikan program E-sosiometri, yang mereka tahu hanya siswa kelas XII saja yang pernah 1 kali diberikan Program sosiometri itupun hanya 1 kali dan diberikan oleh mahasiswa yang melakukan studi kasus.

Kemudian dari penuturan selanjutnya oleh kelas XII yang pernah mendapatkan pelaksanan E-sosiometri, dari 2 orang siswa kelas XII mereka tidak tahu tentang tujuan pelaksanaan Program sosiometri tersebut.

Menurut penuturan keseluruhan obyek wawancara, pemberian Program sosiometri harus sejak dini diberikan agar siswa dapat mengetahui hubungan sosial antar siswa yang satu yang lainnya. Dari penuturan salah satu siswa kelas XI, mereka membutuhkan informasi tentang:

1) Tujuan dan Manfaat E-sosiometri.

2) Mengapa Program sosiometri itu Penting

3) Berapa kali seharusnya guru pembimbing memberikan Program sosiometri ini

Berdasarkan wawancara dengan guru pembimbing dapat disimpulkan bahwa pelaksanaan Program sosiometri sangat minim dalam pelaksanaannya.

Studi literatur. Kegiatan yang dilakukan pada tahap ini adalah dengan melakukan studi literatur (kajian pustaka) utamanya mengenai pengembangan Program sosiometri diantaranya mengenai langkah-langkah, tujuan dan manfaat yang akan dimasukkan dalam pengembangan Esosiometri.

Berdasarkan literatur yang didapatkan, dapat disimpulkan bahwa pengembangan Program sosiometri sebagai media pengungkapan hubungan sosial siswa merupakan salah satu cara untuk mengetahui hubungan sosial siswa.

Perencanaan Pengembangan Produk Awal. Pada tahap perencanaan produk awal, peneliti melakukan observasi pada instrumen yang guru pembimbing biasa berikan kepada siswa yang ada di SMAN 9 Makassar dan pada guru pembimbing untuk mengetahui gambaran tentang pelaksanaan sosiometri yang dapat terlaksana dan layanan yang belum dapat terlaksana. Dari kegiatan tersebut dapat diketahui hambatan-hambatan Program sosiometri yang ditemui oleh guru pembimbing dalam melaksanakan E-Sosiometri.

Dari hasil observasi tersebut, instumen pengumpulan data yang telah dilakukan oleh guru pembimbing kemudian dievaluasi dan mengembangkan instrumen pengumpulan data serta didasarkan pada analisis kebutuhan siswa terhadap Program sosiometri sebagai media pengungkapan hubungan sosial siswa. Dengan melakukan langkah-langkah tersebut di atas maka akan dikembangkan suatu program analisis Program sosiometri sebagai media pengungkapan hubungan sosial.

Pengembangan Produk. Pengembangan produk merupakan langkah dalam menyusun instrumen dan tampilan dari Program sosiometri yang akan disusun. Peneliti membuat Program sosiometri di program Microsoft excel dan menggunakan tampilan desain untuk pembuatan Program sosiometri yang ada Software SociometryPro 2.3. Dalam pembuatan E-sosiometri, peneliti menambahkan instumen yang sudah ada dan melengkapinya dari yang dikembangkan oleh Eko Susanto. Tambahan, antara lain menambahkan intrumen 
bidang bimbingan dan konseling seperti bidang bimbingan belajar, pribadi dan karir, dan menambahkan pula software yang sudah ada menpatenkan untuk tidak di download lagi karena peneliti melihat tujuan sosiometri bukan hanya untuk mengetahui hubungan sosial namun juga dapat menentukan kelompok belajar, teman, sahabat dan studi lanjut siswa.

Selanjutnya peneliti membuat tampilan halaman utama (homepage) Program sosiometri dengan menggunakan password untuk membuka program E-sosiometri. Pemilihan warna pada tampilan halaman utama dipilih karena disesuaikan tempat saya menjalani studi sarjana sebagai warna kebanggan UNM Setelah menentukan tampilan halaman utama dan mengembangkan program yang sudah ada selanjutnya peneliti merancang tampilan Instrumen dan program analisis data Esosiometri.

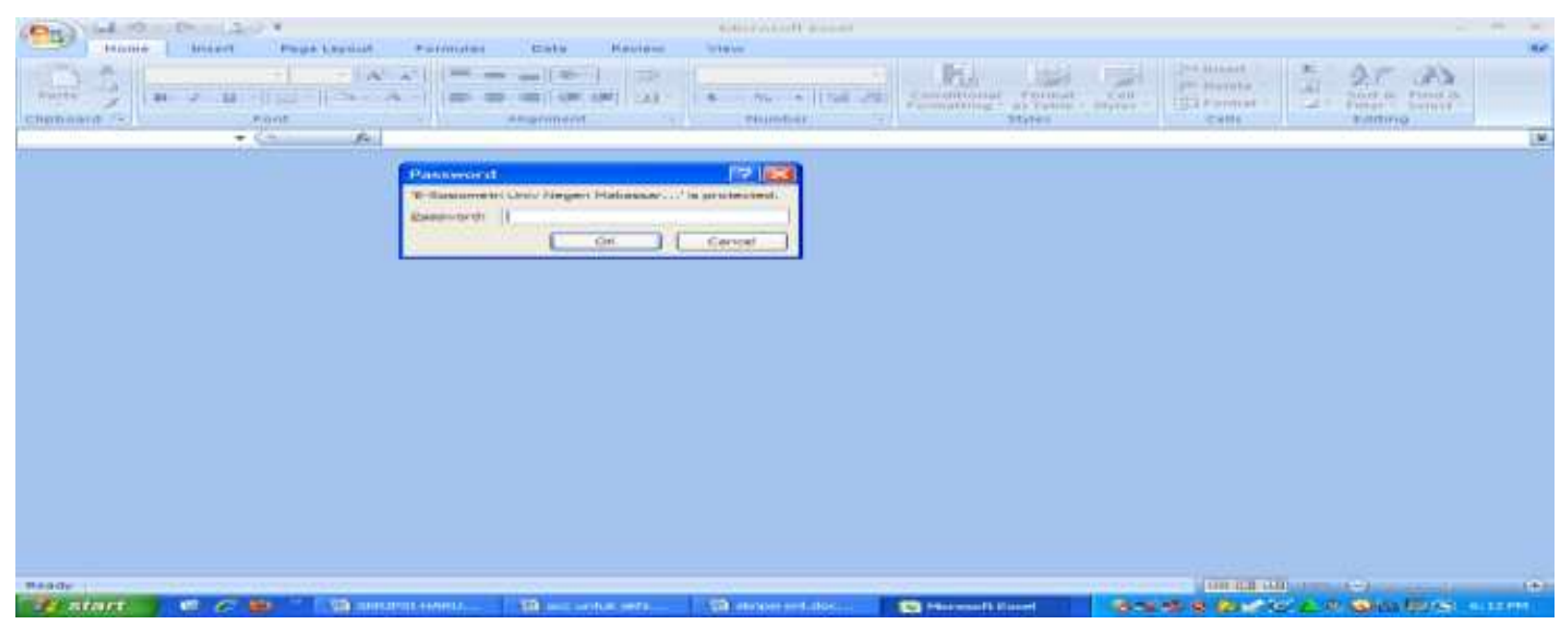

Gambar.1 Tampilan awal membuka E-sosiometri

Validasi Ahli. Wawancara untuk validasi uji ahli, Data yang peneliti peroleh dari ahli instrumen, T.I dan guru pembimbing adalah melalui wawancara, dengan hasil sebagai berikut:

a) Wawancara ahli instrumen yaitu ahli pertama dari dosen mata kuliah Assesmen Psikologis non tes yaitu Drs. H. Muhammad Ibrahim, M.Si sebagai berikut:

1) Kesesuaian dan kebermanfaatan program Program sosiometri secara keseluruhan sudah baik dan sesuai dengan isi instrumen bidang bimbingan dan konseling.

2) Komponen komponen isi instrumen sesuai dengan tujuan dan manfaat sosiometri

b) Wawancara ahli kedua dari dosen sekaligus ketua jurusan Kurikulum dan teknologi pendidikan yaitu Dr. Pattaufi, M.Si sebagai berikut:

1) Tampilan program Program sosiometri sudah jelas namun untuk diberikan ke siswa SMA perlu ditambahkan warna yang terang untuk menarik siswa mengisi instrument

2) Untuk aspek tampilan huruf dan tulisan, ahli IT memberi masukan untuk memperbesar ukurannya huruf instrumen sosiometri agar mengundang seseorang untuk mau mengisi maka ada baiknya tulisan yang digunakan haruslah jelas dan mudah

3) Untuk aspek warna, ahli media mengatakan sudah soft di mata.

c) Wawancara ahli ketiga dari guru pembimbing SMKN 3 Makassar yaitu Drs. Kasrun Kasiran, M.Pd sebagai beriku:

(1) Kesesuaian dan kebermanfaatan program Program sosiometri secara keseluruhan sudah baik dan sesuai dengan isi instrumen bidang bimbingan dan konseling

(2) Model instrumen sudah baik karena sudah memadukan konvensional dan IT dan supaya pemakaian kalimat lebih tepat untuk memaksimalkan bidang yang ingin di ungkap. 
Data kuantitatif. Data kuantitatif di peroleh dari uji kelayakan terhadap program Program sosiometri akan dirincikan satu persatu yaitu uji kelayakan ahli 1, uji kelayakan ahli 2 dan uji kelayakan ahli 3 kemudian akan diperoleh presentase kelayakan.

Hasil Rata-Rata Penilaian Uji Kelayakan Ahli Materi 1,2 \& 3

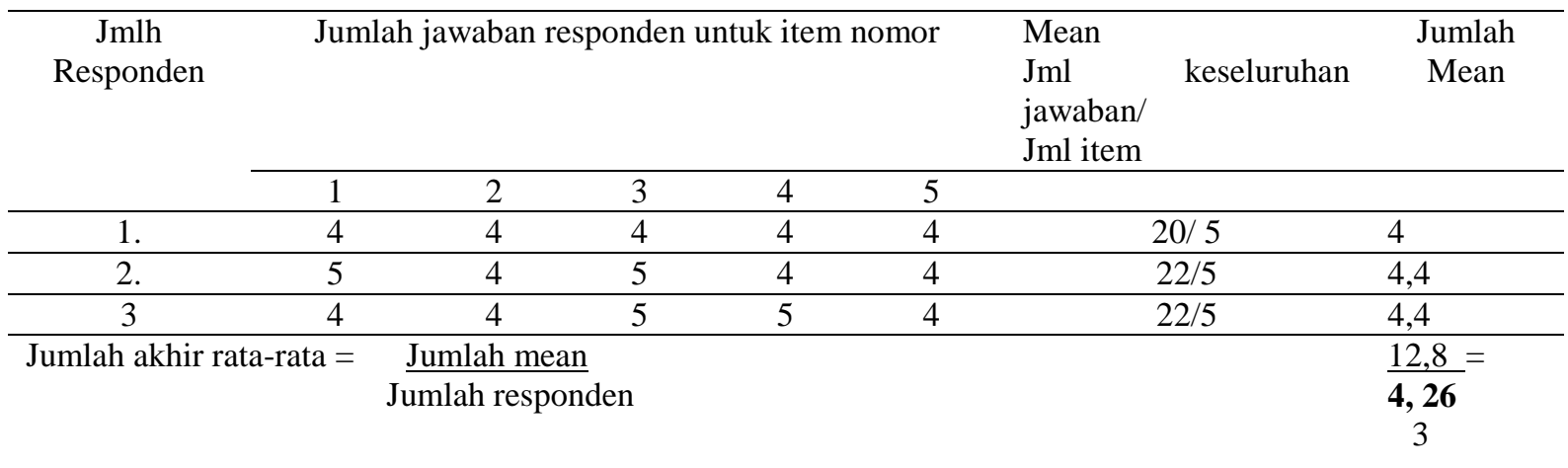

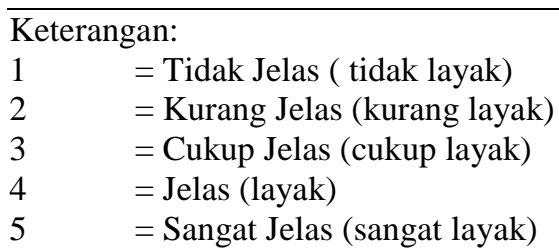

Dari hasil uji kelayakan di atas dapat disimpulkan bahwa produk berupa program Program sosiometri sebagai media pengungkapan hubungan sosial siswa SMA pada skala penilaian 4,26 yang termasuk dalam skala penilaian "jelas" dan dari hal tersebut maka dapat dinyatakan bahwa program Program sosiometri tersebut telah layak untuk dilaksanakan di sekolah.

Uji Coba Produk (uji kelompok kecil). Uji coba produk dilakukan pada kelompok kecil yaitu 6 orang siswa. Uji kelompok kecil dilakukan setelah produk program Program sosiometri sebagai media pengungkapan hubungan sosial siswa SMA direvisi berdasarkan data dari validasi ahli dan dinyatakan layak melalui uji kelayakan. Uji coba dibagi menjadi dua bagian yaitu uji keberterimaan dan uji keterpakaian.

Uji keberterimaan. Uji keberterimaan dilakukan untuk mengetahui tanggapan dan komentar dari siswa dan guru pembimbing mengenai program yang sedang dikembangkan. Berikut hasil wawancara dengan guru pembimbing di SMAN 9 Makassar:
1) Dengan adanya pengembangan program Program sosiometri sebagai media pengungkapan hubungan sosial siswa SMA lebih memudahkan guru pembimbing untuk melaksanakan pelayanan bimbingan dan konseling khususnya dalam mengetahui hubungan sosial siswa.

2) Banyak manfaat yang diperoleh dari adanya program Program sosiometri ini yaitu siswa dapat saling mengenal lebih akrab dengan teman lainnya dan dapat memilih teman untuk diajak kerja sama salah satunya.

3) Mengenai waktu pelaksanaan, saya akan melakukan kerja sama dengan guru pembimbing lainnya sehingga instrumen ini dapat dilaksanakan dengan baik.

4) Mengenai tanggapan siswa pada umumnya merasa senang dengan adanya program ini karena mereka dapat saling mengenal satu sama lain dan dan saling mempercayai dalam hubungan sosial.

Berikut ini disajikan tabel hasil analisis angket penilaian pada uji keberterimaan terhadap program bimbingan Program sosiometri sebagai media pengungkapan hubungan social siswa: 


\begin{tabular}{lcccc}
\hline \multicolumn{1}{c}{ Aspek Penilaian } & \multicolumn{3}{c}{ Hasil Penilaian } \\
\cline { 2 - 5 } & Ya & $\%$ & Tdk & $\%$ \\
\hline 1. Tampilan awal program Sosiometri & 6 & 100 & 0 & 0 \\
\hline 2. Penggunaan huruf, judul dan tulisan program program sosiometri & 6 & 100 & 0 & 0 \\
\hline 3. Tampilan komponen-komponen program program sosiometri & 6 & 100 & 0 & 0 \\
\hline 4. Tata Letak komponen-komponen & 6 & 100 & 0 & 0 \\
\hline 5.Warna tampilan program & 4 & 60 & 2 & 40 \\
\hline 6. Desain tampilan Program & 5 & 80 & 1 & 20 \\
\hline
\end{tabular}

Berikut ini disajikan tabel presentase hasil analisis angket penilaian pada uji keberterimaan:

Presentase Hasil Penilaian Uji keberterimaan produk

\begin{tabular}{|c|c|c|c|}
\hline \multirow{2}{*}{ Aspek Penilaian } & \multicolumn{2}{|c|}{ Hasil Penilaian } & \multirow{2}{*}{$\begin{array}{l}\text { Kategori } \\
\text { Penilaian }\end{array}$} \\
\hline & penilaian & $\begin{array}{l}\text { rata-rata } \\
\text { penilaian }\end{array}$ & \\
\hline 1. Tampilan awal program Sosiometri & $100 \%$ & \multirow{6}{*}{$90 \%$} & \multirow{6}{*}{$\begin{array}{l}\text { Sangat } \\
\text { tinggi }\end{array}$} \\
\hline $\begin{array}{l}\text { 2. Penggunaan huruf, judul dan tulisan program program } \\
\text { Sosiometri }\end{array}$ & $100 \%$ & & \\
\hline 3. Tampilan komponen-komponen program program Sosiometri & $100 \%$ & & \\
\hline 4. Tata Letak komponen-komponen & $100 \%$ & & \\
\hline 5. Warna tampilan program & $60 \%$ & & \\
\hline 6. Desain Tampilan Program & $80 \%$ & & \\
\hline
\end{tabular}

\section{Keterangan:}

$$
\begin{array}{ll}
\text { Interval penilaian: } & \\
80 \%-100 \% & =\text { Sangat Tinggi } \\
60 \%-79 \% & =\text { Tinggi } \\
40 \%-59 \% & =\text { Sedang } \\
20 \%-39 \% & =\text { Rendah } \\
0 \%-19 \% & =\text { Sangat Rendah }
\end{array}
$$

Dari hasil uji keberterimaan guru pembimbing di atas maka dapat disimpulkan bahwa guru pembimbing dapat menerima program Program sosiometri sebagai media pengungkapan hubungan sosial siswa SMAN 9 Makassar. Hal tersebut ditunjukkan pada presentase hasil penilaian pada uji keberterimaan $90 \%$ berada dalam kategori penilaian sangat tinggi.

Uji keterpakaian. Uji keterpakaian dilakukan setelah guru pembimbing di SMAN 9 Makassar melaksanakan uji coba terhadap 3 orang guru pembimbing. Berdasarkan hasil penilaian uji keterpakaian di atas maka dapat disimpulkan bahwa program Program sosiometri

tersebut dinyatakan bahwa program ESosiometridapat dilaksanakan/digunakan di SMAN 9 Makassar.
Revisi Produk: Berdasarkan hasil analisis data yang telah dibahas pada bagian sebelumnya, maka dalam pengembangan program Program sosiometri sebagai media pengungkapan hubungan sosial siswa ini terjadi dua kali tahap revisi.

Revisi Tahap 1: Revisi tahap pertama ini didasarkan pada analisis data yang diperoleh dari validasi ahli yaitu ahli instrumen, T,I dan guru pembimbing. Adapun revisi yang dilakukan adalah revisi terhadap program Program sosiometri sebagai media pengungkapan hubungan sosial siswa yang sedang dikembangkan. Dalam melakukan revisi sebenarnya para ahli sudah mengatakan sudah bagus programnya namun para ahli sedikit menmbahkan saran dan masukan pertama ini peneliti memperjelas isi instrumen Program sosiometri seperti pada bidang pribadi dan belajar. Bentuk revisi yang dilakukan pada revisi 
tahap pertama ini secara rinci adalah sebagai berikut:

1) Bentuk revisi program Program sosiometri berdasarkan masukan ahli instrumen tidak ada karena semuanya sudah sesuai dengan isi instrumen yang seharusnya
2) Bentuk revisi program Program sosiometri berdasarkan masukan ahli T.I adalah sebagai berikut:

a) Warna Program Program sosiometri sudah sesuai dengan Almamater UNM
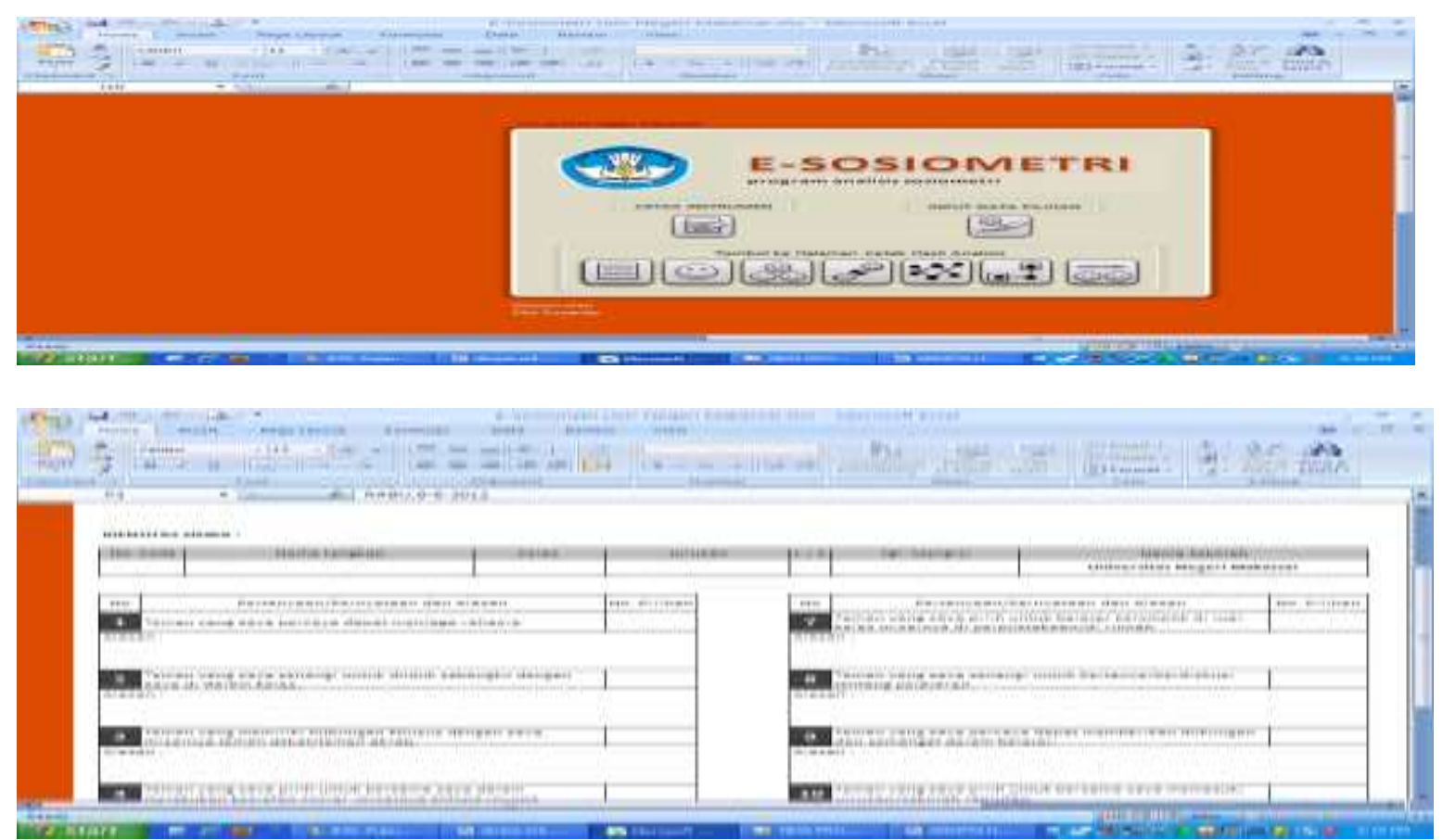

Gambar. 1.2 Tampilan E-Sosiometri

b) Komponen-komponennya program

E-Sosiometri sudah menarik untuk dilihat

c) Ukuran huruf sudah sangat jelas untuk dibaca oleh siswa

3) Bentuk revisi program Program sosiometri berdasarkan masukan guru pembimbing tidak ada karena sudah sesuai dengan isi instrumen yang seharusnya

Program Program sosiometri sebagai media pengungkapan hubungan sosial siswa hasil revisi tahap pertama ini selanjutnya diujikan pada uji coba tahap berikutnya, yaitu uji coba pada kelompok kecil.

Uji coba Kelompok Kecil: Uji coba ini bertujuan untuk mengetahui kelayakan, keberterimaan dan keterpakaian program Program sosiometri yang dikembangkan dan hal apa saja yang perlu direvisi sebelum menentukan produk akhir. Uji coba ini di lakukan kepada guru pembimbing yang ada di sekolah tempat meneliti. Revisi Tahap 2: Revisi tahap kedua dilakukan berdasarkan pada analisis yang dilakukan pada data hasil uji kelompok kecil. Berdasarkan data kuantitatif yang diperoleh menunjukkan bahwa program Program sosiometri sebagai media pengungkapan hubungan sosial siswa tidak perlu direvisi. Adapun revisi tahap dua ini lebih didasarkan pada data kualitatif, berupa saran dan komentar.

Berdasarkan data kuantitatif yang peneliti dapatkan dari validasi ahli, uji kelayakan dan uji keberterimaan dan keterpakaaian maka produk program Program sosiometri sebagai media pengungkapan hubungan sosial telah layak, diterima dan dapat untuk digunakan sebagai pedoman guru pembimbing dalam melaksanakan program Program sosiometri ini. Hal tersebut ditunjukkan oleh hasil revisi pertama dan uji kelayakan yang menunjukkan tingkat kelayakan 4, 26 (dalam kategori layak) dan pada uji keberterimaan memperoleh presentae penilaian sebanyak $90 \%$ (dalam kategori sangat tinggi) 
serta pada uji keterpakaian memperoleh presentae penilaian sebanyak $80 \%$ (dalam kategori sangat tinggi) yang artinya guru pembimbing dapat melaksanakan program Program sosiometri sebagai media pengungkapan hubungan sosial siswa.

Untuk dapat mencapai pelaksanaan Program sosiometri yang efektif, seperti yang peneliti lakukan sebelum merumuskan instrumen program Program sosiometri yaitu melakukan need assesment. Menurut Supriatna (2010) guru pembimbing perlu mengidentifikasi dan merumuskan kebutuhan, tugas-tugas, dan tingkat perkembangan siswa, sebelum merumuskan tujuan dan rancangan program. Need assesment adalah suatu program dapat disusun berdasarkan data yang ditemukan dari lapangan dan bertujuan untuk mengidentifikasi jenis kegiatan apa yang diperlukan dan dimasukkan berdasarkan pengumpulan data yang telah dilakukan.

Merujuk pada penjelasan di atas kegiatan (aktivitas) Program sosiometri pada siswa SMA harus bisa mengantar setiap pelajar untuk menciptakan hubungan sosial yang optimal sebab mengingat remaja SMA mereka berada pada fase transisi dari dunia anak ke dunia dewasa. Mereka harus menggunakan masa remajanya untuk bersiap melakukan berbagai peran yang harus dilaksanakan pada masa dewasanya. Dengan demikian lebih memudahkan guru pembimbing dalam pelaksanaan Program sosiometri Program ini memberi kemudahan pada guru pembimbing karena didalam program Program sosiometri sebagai media pengungkapan hubungan sosial siswa yang dikembangkan ini, merujuk pada kebutuhan siswa itu sendiri dan merujuk pada hubungan sosial siswa yang satu dan lainnya. Dengan merujuk kepada tahapan pelaksanaan Esosiometri, maka kebutuhan dalam menciptakan hubungan sosial dapt optimal.

\section{SIMPULAN DAN SARAN}

Secara keseluruhan program Program sosiometri sebagai media pengungkapan hubungan sosial siswa yang dikembangkan berisi berbagai macam komponen program yaitu sosiogram, profil individu dan kelompok, tabulasi data, grafik

Program Program sosiometri yang dikembangkan sesuai dengan sasaran disusunnya program Program sosiometri tersebut, instrumen sudah tepat sasaran dan sudah mencakup bidang BK yaitu pribadi, sosial, belajar dan karir. Berdasarkan hasil revisi 1 dan uji kelayakan program Program sosiometri sebagai media pengungkapan hubungan sosial siswa tersebut mendapatkan skala penilaian rata-rata sebanyak 4, 26 berada dalam kateori layak dan setelah dilakukan revisi 2 dari uji keberterimaan program Program sosiometri sebagai media pengungkapan hubungan sosial siswa memperoleh penilaian $90 \%$ berada dalam kategori sangat tinggi serta pada uji keterpakaian setelah guru pembimbing melaksanakan program Program sosiometri memperoleh presentase penilaian $90 \%$ dalam kategori sangat tinggi.

Berdasarkan hasil revisi, uji ahli (uji kelayakan) dan uji kelompok kecil (uji keberterimaan dan keterpakaian) maka program Program sosiometri sebagai media pengungkapan hubungan sosial telah dinyatakan layak, diterima dan bisa dilaksanakan di sekolah SMAN 9 Makassar. Berdasarkan hasil penelitian yang telah dilakukan dan dinyatakan bahwa program Program sosiometri sebagai media pengungkapan hubungan sosial siswa telah dinyatakan layak dan bisa dilaksanakan di sekolah SMAN 9 Makassar. Berikut ini merupakan beberapa saran terkait dengan produk yang dihasilkan: 1) Bagi Kepala Sekolah, agar dapat merekomendasikan kepada Guru pembimbing untuk menggunakan program Program sosiometri sebagai media pengungkapan hubungan sosial siswa agar dapat melaksanakan program BK yang sesuai dengan kebutuhan akan hubungan sosial siswa. 2) Bagi guru Pembimbing agar dapat menggunakan program Program sosiometri sebagai proses pelayanan bimbingan dan konseling di sekolah dan digunakan seefektif mungkin sehingga hubungan sosial siswa khususnya dapat berjalan secara optimal.3) Bagi Jurusan Psikologi Pendidikan dan Bimbingan, dapat merekomendasikan program Program sosiometri sebagai media pengungkapan hubungan sosial siswa merupakan salah satu cara dalam rangka membantu guru pembimbing disekolah dalam mengungkap hubungan sosial siswa. 4) Bagi peneliti dan mahasiswa psikologi pendidikan dan bimbingan, hasil penelitian pengembangan ini dapat dijadikan salah satu contoh dalam penyusunan pengembangan program bimbingan dan konseling yaitu program inventori, angket, observasi program Program sosiometri ini lebih 
lanjut. Hal ini dikarenakan masih terdapat beberapa kekurangan dalam proses pengembangan program Program sosiometri ini, selain itu perlu dilakukan penelitian lebih lanjut mengenai efektifitas program Program sosiometri sebagai media pengungkapan hubungan sosial siswa pada siswa.

\section{DAFTAR RUJUKAN}

Abimanyu, S. 1983. Teknik Pemahaman Individu (Teknik Non Tesing). Makassar. FIP UNM

Ali dan Asrori, 2004. Psikologi Remaja. Jakarta: Bumi Aksara.

Borg, Walter and Meredith Damien Gall. 1983. Education Research and Introduction. Fourth Edition. New York: Longman Inc

Eko Susanto. 2009. Pengolahan Sosiometri dengan Aplikasi Komputer. Bandung: UPI

Moreno, Jacob Levy. 1953. Who Shall Survive? Revised Edition. Beacon: NY: Beacon House.

Rusmana, N. 2009. Sosiometri2. (online), http://www.sosiometri.index.php.htm (diakses 31 Mei 2012

Sarwono. 1996. Psikologi Remaja. Jakarta: Raja Grafindo Persada

Siahaan, HM. 2005. Sosiometri2. http://www.sosiometri.index.php.htm(o $\underline{\text { nline) }}$ diakses 31 Mei 2012.

Wasis. 2004. Manajemen Penelitian. Jakarta: PT. Rineka Cipta. 